\title{
Bacterial Population Dynamics of Natural Fermentation of Sumbawa Mare's Milk Using Metagenomic Approach
}

\author{
YOGA DWI JATMIKO $^{1 *}$, ADITYA RAGIL SUHARTO ${ }^{1}$, IRFAN MUSTAFA ${ }^{1}$, AND SISKA ADITYA $^{2}$
}

\author{
${ }^{1}$ Department of Biology, Universitas Brawijaya, Malang 65145, Indonesia; \\ ${ }^{2}$ Faculty of Veterinary Medicine, Universitas Brawijaya, Malang 65145, Indonesia.
}

\begin{abstract}
Naturally fermented Sumbawa mare's milk is a mare's milk product that has been fermented naturally involving indigenous microbes. Studies of bacterial communities during the fermentation of mare's milk based on metagenomic method remains limited. This study aimed to assess the changing of bacterial density and the physicochemical aspects during natural fermentation of Sumbawa mare's milk and to evaluate the dynamics of the bacterial population during the natural fermentation using a metagenomic approach. Mare's milk samples obtained from Regency of Dompu were fermented for 60 day. On the day 0, 7, 15, 30 and 60 mare's milk sample were collected for further analysis, such as bacterial density enumeration, nutrition content, physical properties of the milk, and total DNA isolation. The total DNA samples obtained were analyzed using next-generation sequencing. The density of lactic acid bacteria decreased along with fermentation periods in MRS and M17 media. Meanwhile, the density of aerobic bacteria in PCA medium relatively fluctuated. The physicochemical content of mare's milk also changed during fermentation periods. Carbohydrate content and total sugar decreased along with the decreasing $\mathrm{pH}$ value. Moreover, the lipid content was increased, and the protein content fluctuated. The changes in physical properties such as whey color, acidity, and gas formation were observed until the end of fermentation process. Using metagenomics analysis, the bacterial diversity from each sample period was categorized as low because Lactobacillus helveticus was dominant until the end of the fermentation. Lactobacillus helveticus as a member of LAB did not grow on isolation media on the late fermentation period (day 60). The presence of uncultivable bacteria can be detected with a metagenomic approach, fulfilling the limited information on the bacterial composition of fermented Sumbawa mare's milk products.
\end{abstract}

Key words: bacterial diversity, natural fermentation, next generation sequencing, Sumbawa mare's milk

Susu kuda Sumbawa terfermentasi merupakan produk susu kuda yang difermentasi secara alami dengan melibatkan mikrobia indigenous. Kajian tentang komunitas bakteri selama fermentasi susu kuda berdasarkan metode metagenomik masih terbatas. Penelitian ini bertujuan untuk mengetahui perubahan densitas bakteri dan aspek fisikokimia selama fermentasi alami susu kuda Sumbawa, dan mengetahui dinamika populasi bakteri selama fermentasi alami dengan menggunakan pendekatan metagenomik. Sampel susu kuda yang berasal dari Kabupaten Dompu, Provinsi Nusa Tenggara Barat difermentasi secara alami pada suhu ruang selama 60 hari. Pengambilan sampel susu dilakukan pada hari ke- 0, 7, 15,30 dan 60 untuk dilakukan uji lebih lanjut. Uji yang dilakukan meliputi enumerasi bakteri, pengukuran kandungan nutrisi, pengamatan sifat fisik susu, dan isolasi DNA total. Sampel DNA total yang didapatkan dilakukan analisis next generation sequencing. Densitas bakteri asam laktat pada media MRS agar dan M17 agar mengalami penurunan seiring periode fermentasi. Sedangkan densitas bakteri aerobik pada media PCA cenderung mengalami fluktuasi. Faktor fisikokimia susu kuda Sumbawa mengalami perubahan selama periode fermentasi. Kandungan karbohidrat dan total gula mengalami penurunan seiring dengan turunnya nilai $\mathrm{pH}$. Sedangkan kadar lemak mengalami peningkatan, dan kandungan protein mengalami fluktuasi seiring periode fermentasi. Perubahan sifat fisik susu kuda yang diamati sampai akhir fermentasi antara lain perubahan warna whey menjadi kuning, aroma yang semakin asam, dan terbentuknya gas. Hasil analisis metagenomik diperoleh informasi bahwa indeks diversitas bakteri pada sampel di setiap periode fermentasi tergolong rendah yang ditandai dengan adanya dominansi Lactobacillus helveticus sampai akhir periode fermentasi. Lactobacillus helveticus yang merupakan anggota BAL tidak tumbuh pada media isolasi di akhir periode fermentasi. Keberadaan bakteri yang tidak dapat dikulturkan ini dapat diketahui melalui pendekatan metagenomik, yang melengkapi informasi komposisi bakteri pada produk susu kuda Sumbawa terfermentasi.

Kata kunci: diversitas bakteri, fermentasi alami, next generation sequencing, susu kuda Sumbawa

Milk is a promising food commodity in Indonesia. Milk production in Indonesia is still dominated by cow's milk with an increasing rate of $9.80 \%$ per year or 905.49

*Corresponding author: Phone: +62-341-575841; Fax: +62341-554403;E-mail:jatmiko_yd@ub.ac.id thousand tons per year (Data Center and Information System for Agriculture 2019). However, the demand for fresh milk and its derivative products continues to increase. Hence, alternatives to milk other than cows are important to be introduced to consumers. A promising milk commodity is mare's milk. Mare milk is rich in 
essential nutrients and is recommended to be the alternative to human milk because their whole protein and salt content are comparable (Malacarne et al. 2002). Sumbawa mare's milk is an Indonesian local commodity, mainly produced as a small scale by local household in Sumbawa Island, especially Bima, Dompu, and Sumbawa Regency. Sumbawa mare's milk is marketed nationwide as naturally fermented milk.

Natural fermentation of mare's milk especially Sumbawa mare's milk contain an array of natural microbes and some of them exert beneficial health effects (Sujaya et al. 2008; Shi et al. 2012). The natural fermentation process is mainly dominated by lactic acid bacteria species such as Lactococcus lactis subsp. cremoris, Lactobacillus casei/Lb. paracasei, Lb. plantarum and Lb. acidophilus. Besides lactic acid bacteria activity, acetic acid bacteria and yeast also contributed to texture formation and aroma during the natural fermentation of mare's milk (Spinnler et al. 2001). Natural fermentation is a process that lacks hygiene, therefore, bacterial contaminants from surrounding environment were detected in this product. As discussed by Mulyawati et al. (2019), they detect the potential pathogen bacteria from genera Staphylococcus and Ochrobactrum in the fermented Sumbawa mare's milk. It was more likely that these bacteria gained access to the product during milking process and associated with the fermentation utensils. Therefore, the information of population dynamic during natural fermentation of Sumbawa mare's milk is important to be elucidated as the foundation of quality control and further development of Sumbawa mare's milk product.

Microbial diversity analysis of milk fermentation can be done using a culture-dependent as well as metagenomics approach or using the combination of both approaches. Culture-dependent is a conventional method that depends on growing microbes on conventional growth medium, this method is limited to the viable-bacteria in the medium. Meanwhile, there are many non-cultivable bacteria that undetected during the cultivation. Metagenomics is a method that directly isolate the genome from environment to define the diversity and functional structure of the microbe (Hoyles \& Swann 2019). Using the combination of metagenomics and culture-dependent approach can generate complex data that give a preview of the natural fermentation process of Sumbawa mare's milk. This experiment was focused on the changing of bacterial density, population dynamic, and physicochemical aspect during the natural fermentation of Sumbawa mare's milk.

\section{MATERIALS AND METHODS}

\section{Sample Collection and Fermentation of} Sumbawa Mare's Milk. Sumbawa mare's milk was freshly collected from Sumbawa horse breeder in Dompu Regency, West Nusa Tenggara Province, Indonesia. After milking, the mare's milk was placed in a sterile container and transported on ice to the laboratory for further analysis. The Sumbawa mare's milk $(1.5 \mathrm{~L})$ was transferred into five sterile glass bottles, and each bottle was filled with $200 \mathrm{~mL}$ of fresh mare's milk. The natural fermentation process was performed by incubating the mare's milk for 60 day at room temperature. Samples of fermented mare's milk were withdrawn at five distinct times: 0 (on the day the milk was received), 7, 15, 30, and 60 days. The subsamples of $100 \mathrm{~mL}$ each were collected for physicochemical analyses, $25 \mathrm{~mL}$ sample for bacterial isolation, $25 \mathrm{~mL}$ sample for $\mathrm{pH}$ measurement, $25 \mathrm{~mL}$ of sample for physical change observation, and $5 \mathrm{~mL}$ of sample for total DNA extraction.

Isolation and Enumeration of Bacteria. Bacterial isolation was conducted by collecting $25 \mathrm{~mL}$ mare's milk sample in every fermentation period. Afterward, the sample was eluted to $225 \mathrm{~mL}$ of saline water $(\mathrm{NaCl} 0.85 \%)$, and then serially diluted 10 -fold $\left(10^{-1}\right.$ to $\left.10^{-7}\right)$. Then, $1 \mathrm{~mL}$ aliquot of each diluted sample was used to determine the bacterial counts (CFU) by pour plate method with de Man, Rogosa and Sharp (MRS)-agar and M17 agar supplemented with $\mathrm{CaCO}_{3}$ $1 \%$ to isolate Lactobacillus and Lactococcus group respectively (De Man et al. 1960; Süle et al. 2014). Plate Count Agar (PCA) was used to isolate aerobic heterotrophic bacteria. The plates were incubated at $37^{\circ} \mathrm{C}$ for $24-48$ hours, and the total colony was determined. Lactic acid bacteria colonies were shown by the presence of clear zone around the colonies.

Physicochemical Analyses. Sample of naturally fermented mare's milk was collected from each fermentation period $(0,7,15,30$, and 60 days) for proximate analysis including ash, carbohydrate, fat, rough fiber, and water content, and total sugar based on the AOAC method. Physical properties of Sumbawa mare's milk including color, odor, texture, and gas formation was observed qualitatively. The $\mathrm{pH}$ value was measured using a digital $\mathrm{pH}$ meter.

DNA Extraction. The DNA for metagenomic analysis was extracted from the samples collected in every fermentation period $(0,7,15,30 \& 60$ days $)$. A 
total of $5 \mathrm{~mL}$ sample was firstly added with $45 \mathrm{~mL}$ trisodium citrate $2 \%$ buffer. The mixture was then incubated for 5 minutes and homogenized for 1 minute using a vortex. Subsequently, the mixture was centrifuged at $12000 \mathrm{rpm}$ for 1 minute at room temperature. The resulting pellet was collected and used for total DNA extraction. The total DNA was extracted with DNeasy Powerfood Microbial Kit (Qiagen, Inc), using the manufacturer's instruction. The concentration and purity of the genomic DNA was checked with a NanoDrop 2000 spectrophotometer (NanoDrop Technologies, USA) and 1.5\% agarose gel electrophoresis. Pure DNA samples were stored at $20^{\circ} \mathrm{C}$ until to be used for next-generation sequencing.

Next-Generation Sequencing and Bioinformatic Analysis. Total DNA with a concentration at least $0,1 \mathrm{ng} / \mu \mathrm{L}$ were sent to NGS Facility Macrogen, Inc., South Korea. Sequencing process were using $16 \mathrm{~S}$ rRNA region V3-V4 (341F: 5'C C TA C G G G N G G C W G C A G - 3 ' ; $805 \mathrm{R}$ : 5'GACTACHVGGGTATCTAATCC-3') (Klindworth et al. 2013). The sequencing was performed on an Illumina MiSeq platform. The paired-end sequences were analyzed using QIIME2 2019.4. and changed into a manifest. The manifest was used to show the exact location of the file so it can be imported and analyzed using QIIME2 (Bolyen et al. 2019). The sequence reads obtained were demultiplexed and quality processed using DADA2 (Callahan et al. 2016). A high-quality sequence reads were further considered to generate species diversity estimation using Shannon diversity index. The 16S rDNA reference alignment, and taxonomical assignation were based upon the Greengenes database as the reference (McDonald et al. 2012).

\section{RESULTS}

Physicochemical Properties. After 60 day of natural fermentation process of Sumbawa mare's milk, several physical changes were observed such as aroma, texture, color change, and gas formation as summarized in Table 1. The fermentation process of the mare's milk created a distinct characteristic that different from other milk products. The aroma of mare's milk getting more acidic during the fermentation periods, followed by changing of the milk color on day 30 until the end of the fermentation period. The texture of the milk was watery, and the gas formation was detected at every fermentation period, marked by the increasing pressure of the gas to the bottle cap.

The nutrient content value of Sumbawa mare's milk varied in every period of the natural fermentation process, indicating the change in the nutrient content of the milk (Table 2). The natural fermentation process of Sumbawa mare's milk allowed the carbohydrate and total sugar content gradually decreased during fermentation period. It was followed by the decrease of $\mathrm{pH}$ from 3.66 in the initial period to 3.37 on day 60 . Fat content on day 0 had a value of $1.41 \%$ and decreased until day 15 up to $1.26 \%$. In the following periods, the fat content value increased until day 60 by $1.65 \%$. Meanwhile, the protein content of Sumbawa mare's milk during the natural fermentation process increased in the beginning of the fermentation, from $1.15 \%$ on day 0 to $1.88 \%$ on day 7 . After day 7 , the protein content gradually decreased until end of fermentation $(1.07 \%)$. During natural fermentation period, ash content on the milk slightly increased from $0,39 \%$ (day 0 ) to 0.43 (day 60), and water content gradually increased from $91.53 \%$ on day 0 to $96.32 \%$ on day 60 . Ash content of Sumbawa mare's milk during the natural fermentation process was low but slightly increased from $0.39 \%$ to $0.43 \%$ in the end of the fermentation.

Bacterial Density. Bacterial population dynamic during the natural fermentation process of Sumbawa mare's milk can be observed through the changing of bacterial density. Three groups of bacteria were observed including aerobic bacteria, rod-shaped lactic acid bacteria (Lactobacillus), and coccus-shaped lactic acid bacteria (Lactococcus). During five periods of natural fermentation $(0,7,15,30$, and 60 days), each growth medium had different variations of bacterial number (Table 3). Bacterial density from three media had an average of $1.87 \log \mathrm{CFU} / \mathrm{mL}$, ranging from $0 \log$ $\mathrm{CFU} / \mathrm{mL}$ to $3.50 \log \mathrm{CFU} / \mathrm{mL}$.

Growth medium for lactic acid bacteria (MRS agar and $\mathrm{M} 17$ agar, both with the addition of $\mathrm{CaCO}_{3} 1 \%$ ) had high density at the early period of fermentation. The MRS agar showed the highest cell density on day 7 (3.50 $\log \mathrm{CFU} / \mathrm{mL}$ ) and the M17 agar had the highest value on day $0(2.62 \log \mathrm{CFU} / \mathrm{mL})$ (Table 3$)$. However, in the following periods, the bacterial cell density decreased on both media, until $0 \log \mathrm{CFU} / \mathrm{mL}$ in the last period. Meanwhile, bacterial cell density on PCA medium relatively fluctuated. On day 0 , the bacterial density was $3.02 \log \mathrm{CFU} / \mathrm{mL}$ and increasing up to 3.23 $\log \mathrm{CFU} / \mathrm{mL}$ on day 7 . But the bacterial cell density decreased until day 30 reaching $2.04 \log \mathrm{CFU} / \mathrm{mL}$ and increased again on day 60 up to $2.90 \log \mathrm{CFU} / \mathrm{mL}$. 
Table 1 Physical properties of Sumbawa mare's milk during the natural fermentation process

\begin{tabular}{cccccc}
\hline Parameters & \multicolumn{5}{c}{ Fermentation periods (day) } \\
& $\mathbf{0}$ & $\mathbf{7}$ & $\mathbf{1 5}$ & $\mathbf{3 0}$ & $\mathbf{6 0}$ \\
\hline Aroma & Sour & Sour & Strongly & Strongly & Strongly \\
& & & sour & sour & sour \\
Texture & Watery & Watery & Watery & Watery & Watery \\
Color & White & White & Cloudy & Yellowish & Yellowish \\
& & & white & & \\
Gas formation & Yes & Yes & Yes & Yes & Yes \\
\hline
\end{tabular}

Table 2 Nutrient content of Sumbawa mare's milk during the natural fermentation process

\begin{tabular}{cccccc}
\hline Parameter & \multicolumn{5}{c}{ Fermentation periods (day) } \\
& $\mathbf{0}$ & $\mathbf{7}$ & $\mathbf{1 5}$ & $\mathbf{3 0}$ & $\mathbf{6 0}$ \\
\hline Carbohydrates (\%) & 5.52 & 4.41 & 4.53 & 1.37 & 0.53 \\
Protein (\%) & 1.15 & 1.88 & 1.57 & 1.46 & 1.07 \\
Fat (\%) & 1.41 & 1.31 & 1.26 & 1.62 & 1.65 \\
Water (\%) & 91.53 & 92.29 & 92.25 & 95.17 & 96.32 \\
Ash (\%) & 0.39 & 0.38 & 0.39 & 0.38 & 0.43 \\
Crude fiber (\%) & 0.04 & 0.02 & 0.03 & 0.02 & 0.01 \\
Total sugar (\%) & 3.11 & 2.96 & 1.89 & 0.59 & 0.19 \\
pH & 3.66 & 3.59 & 3.37 & 3.4 & 3.37 \\
\hline
\end{tabular}

Table 3 Bacterial density during the natural fermentation process of Sumbawa mare's milk

\begin{tabular}{cccccc}
\hline Culture medium & \multicolumn{5}{c}{ Bacterial cell number $(\log 10$ CFU/mL) } \\
& Day 0 & Day 7 & Day 15 & Day 30 & Day 60 \\
\hline MRS agar & 3.14 & 3.50 & 1.95 & 0 & 0 \\
M17 agar & 2.62 & 2.51 & 0 & 1 & 0 \\
PCA & 3.02 & 3.23 & 2.23 & 2.04 & 2.90 \\
\hline
\end{tabular}

Table 4 Genomic analysis and bacterial diversity during natural fermentation of Sumbawa mare's milk

\begin{tabular}{ccccccc}
\hline \multirow{2}{*}{$\begin{array}{c}\text { Fermentation } \\
\text { periods }\end{array}$} & No. of reads & \multirow{2}{*}{$\begin{array}{c}\text { No. of } \\
\text { OTU }\end{array}$} & \multicolumn{3}{c}{ Diversity Indices } & \multicolumn{2}{c}{$\begin{array}{c}\text { No. of observed } \\
\text { species }\end{array}$} \\
\cline { 5 - 7 } & 25193 & 45 & 3.76 & 0.90 & 4.34 & 12 \\
Day 0 & 44511 & 32 & 3.66 & 0.89 & 2.89 & 9 \\
Day 7 & 35636 & 40 & 3.46 & 0.88 & 3.72 & 15 \\
Day 15 & 17852 & 42 & 3.81 & 0.91 & 4,18 & 16 \\
Day 30 & 48687 & 110 & 3.59 & 0.88 & 10.09 & 76 \\
Day 60 & $34375.80 \pm$ & $53.80 \pm$ & $3.66 \pm$ & $0.89 \pm$ & $5.04 \pm$ & $25.60 \pm 28.31$ \\
\hline Mean \pm SD & 12908.14 & 31.78 & 0.14 & 0.01 & 2.88 & \\
\end{tabular}

\section{Bacterial Diversity in Different Periods of} Natural Fermentation. Genomic sequencing of five periods of the natural fermentation process of Sumbawa mare's milk generated high quality reads ranged from 17852 to 48687 (average 34375.80 reads), corresponding to a total of 269 OTUs (average 53.80 OTUs). Alpha diversity of five periods was determined using three indices (Table 4). Shannon indices,
Simpson indices, and Margalef indices ranged from 3.46 to $3.81,0.88$ to 0.91 , and 2.89 to 10.09 , respectively. Shannon and Simpson indices indicate species diversity in a sample. According to these indices, the highest diversity was achieved on day 30 , followed by day 0 . Based on the Margalef index, it was known that on the day 60 has high species richness. The value of Margelef index correlated with the number of 
observed species. The total observed species during the natural fermentation process of Sumbawa mare's milk was 128. Alpha rarefaction curve also generated based on observed OTUs in every fermentation period (Figure 1). The plots reached the plateau indicated that the sampling depth and sequencing coverage were good for all samples.

Bacterial Composition. A total of 110 OTUs containing 20 phyla, 32 classes, 44 orders, 63 families, 73 genera, and 89 species were observed. Five periods of fermentation showed similar bacterial structures at the phylum level. The most dominant phylum was Firmicutes with relative frequency of day $0,7,15,30$ and 60 were $97.71 \%, 98.38 \%, 98.56 \%, 98.24 \%$, and $96.12 \%$, respectively. There were several other phyla including Proteobacteria, Bacteriodes, Actinobacteria, and Acidobacteria (Figure 2A.).

Bacterial structure at the genus level was dominated by Lactobacillus during the first period until the last period of natural fermentation. The relative frequency Lactobacillus fluctuated from day 0 to 7 with increased from $92.55 \%$ to $95.87 \%$. However, in the subsequent periods, the relative frequency was decreased. From day 15 to 60 the relative frequency was $94.45 \%, 80.31 \%$, and $91.79 \%$, respectively (Figure 2B.). On day 30, the relative frequency dropped to $80.31 \%$, but there was an increase in family Lactobacillaceae to $14.53 \%$ (Figure 2B.).

The increasing amount of relative frequency on the family Lactobacillaceae has occured because the database cannot assign the sequence until the genus level. Another lactic acid bacteria group observed was Lactococcus. Their relative frequency was not as high as the Lactobacillus group, but their population dynamic during natural fermentation was also notable. Lactococcus frequency decreased on day 0 to 7 , from $4.25 \%$ to $2.512 \%$, but their relative frequency rose again to $4.09 \%$ on day 15 . In the following periods, the relative frequency of Lactococcus decreased until $0.67 \%$ at day 60 (Figure 2B.).

At the species level, Lactobacillus helveticus was the most dominant species during the natural fermentation (Figure 2C). Their relative frequency was fluctuated. In the early period of fermentation (day 0 to day 7), the relative frequency increased from $89.20 \%$ to $95.51 \%$. But after day 7 , their relative frequency decreased from $93.51 \%$ (day 15 ), $78.61 \%$ (day 30 ) to $91.07 \%$ (day 60 ) (Figure 2C). Besides Lactobacillus helveticus, several groups of lactic acid bacteria such as Lactococcus, Lactobacillus zeae, Lactobacillus pontis, and Lactobacillus delbrueckii were observed in an insignificant relative frequency. Also, on day 60, Methylobacterium komagatae $(0.39 \%)$ was also observed (Figure 2C).

Besides lactic acid bacteria groups, there was other potential pathogenic bacteria from the member of family Enterobacteriaceae, such as Citrobacter and Methylobacterium komagatae (Figure 2C). A low number of uncultured and uncharacterized bacteria (others) were identified in the fermented mare's milk using NGS, with the relative frequency in the fermentation process ranging from $0.1-2.49 \%$. The highest relative frequency of other group was achieved on day $60(2.49 \%)$.

\section{DISCUSSION}

During natural fermentation, Sumbawa mare's milk undergone several changes in its physicochemical properties. First, the aroma of the milk became more acidic. It was correlated with the $\mathrm{pH}$ value that keeps decreasing until the last period of natural fermentation. Natural fermentation of the mare's milk was performed by lactic acid bacteria and acetic acid bacteria that already exist in the milk (Yao et al. 2017; Gemechu 2015). The longer the fermentation process, the milk color changed to yellowish. Changing the color of the mare's milk could happen due to a reaction between vitamin $\mathrm{B}_{2}$ (riboflavin) and lactose on milk (Goulding et al. 2020). Therefore, this hypothesis requires to be proven because the vitamin content was not measured in this study.

The milk fermentation process utilizes carbohydrates and converting them to organic acids (lactic acid and acetic acid), and $\mathrm{CO}_{2}$ (Widyastuti et al. 2014). As a result, the carbohydrates and total sugar content in the Sumbawa mare's milk gradually decreased during the fermentation periods. The low carbohydrates and sugar content on the late period of natural fermentation (day 30 and day 30) limit the growth of the lactic acid bacteria group. Low sources of energy and nutrient can restrain bacterial growth (Barboza et al. 2009).

The total protein content of the milk decreased during the fermentation periods. Lactic acid bacteria activity in the milk needs amino acid to support their existence (Savijoki et al. 2006). In fact, the amount of amino acid in the milk was insufficient. To handle this situation, lactic acid bacteria possess complex proteinase and peptidases to enable them to produce essential amino acids for their growth (Tzvetkova et al. 2007). Hydrolysis protein also provides a health 


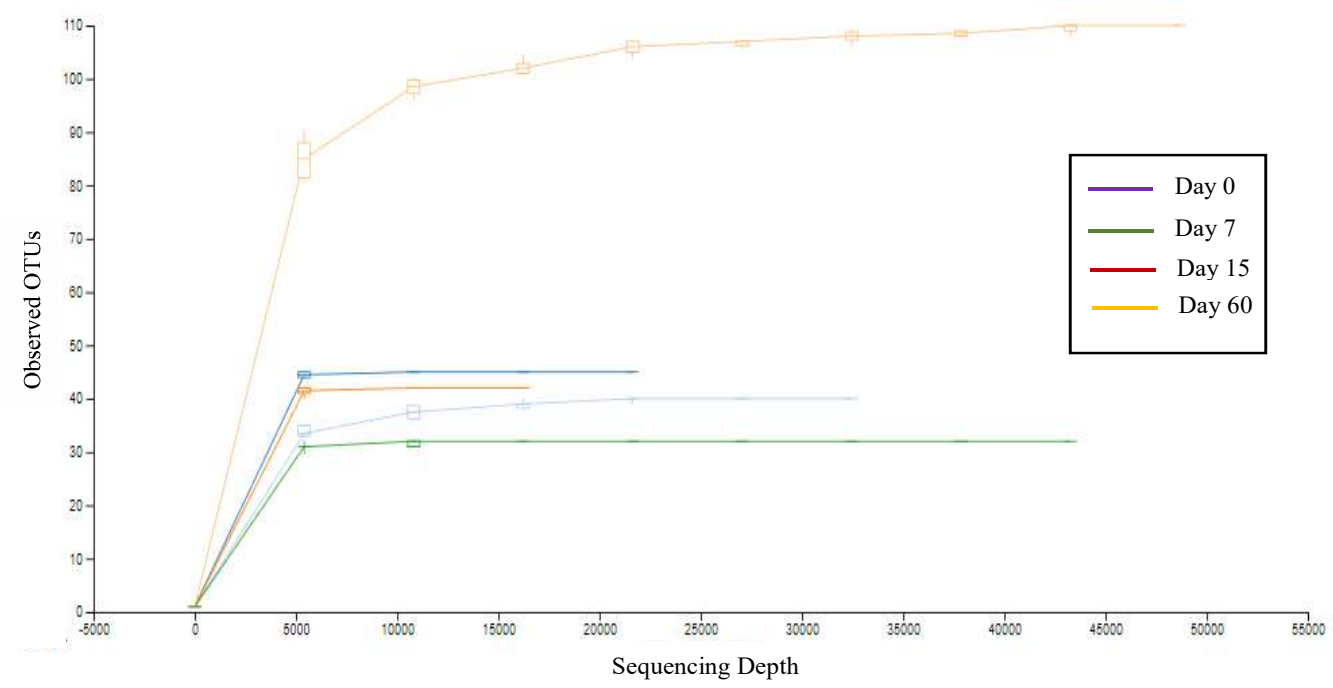

Fig 1 Alpha rarefaction curve from five periods of the natural fermentation process of Sumbawa mare's milk.
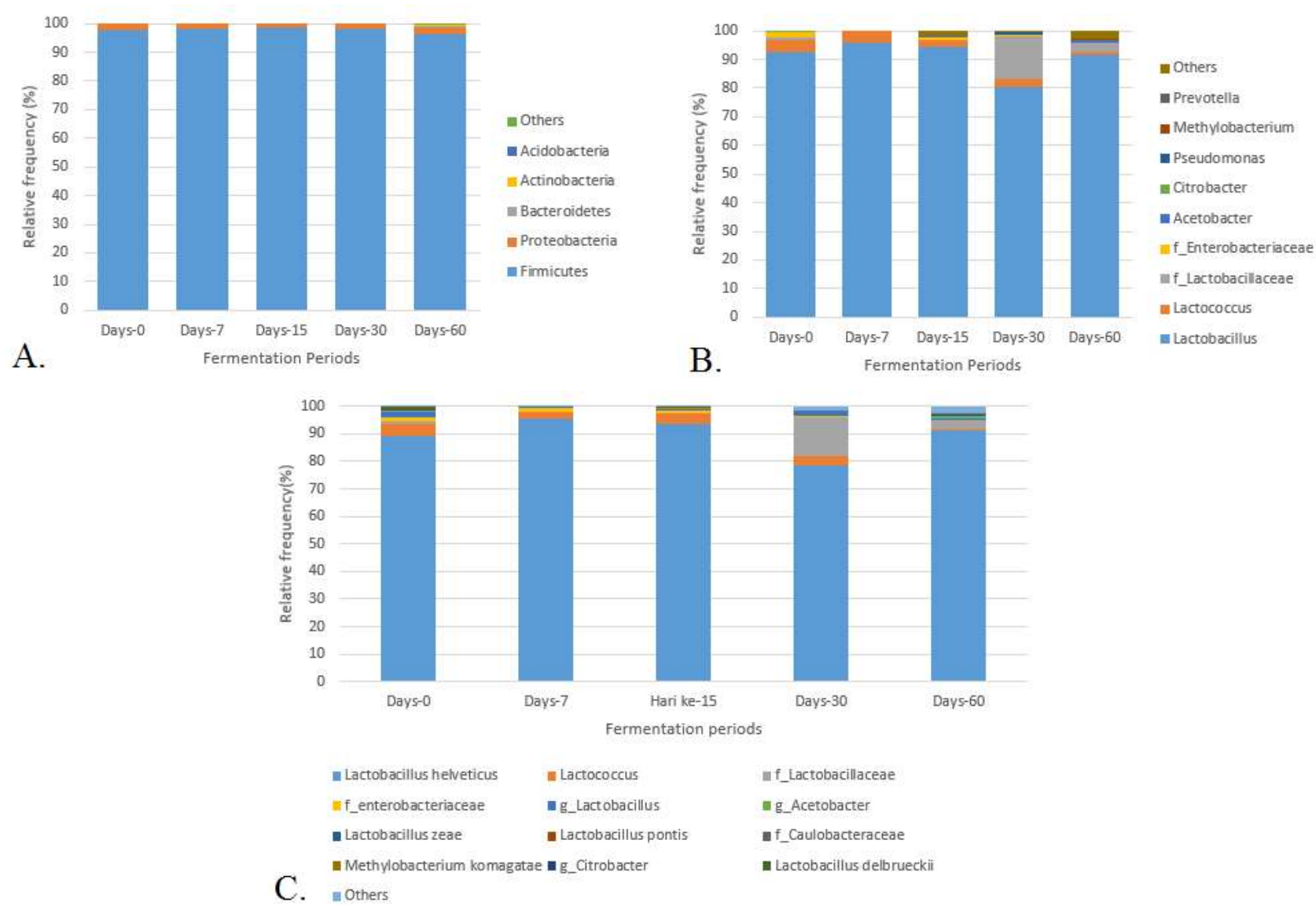

Fig 2 Bacterial composition during natural fermentation of Sumbawa mare's milk. (A) Phylum level. (B) Genus level. (C) Species level.

benefit to humans due to the reduction of the milk allergenicity. Species from the LAB group such as, Bifidobacterium lactis can hydrolyze $\beta$-lactoglobulin, which is the strongest antigen leading to milk allergy (Prioult et al. 2005).

The total fat content on mare's milk is the lowest compare to other livestock, the average fat content in mare's milk is $1.67 \%$ (Uniacke-Lowe et al. 2010). The total fat content of Sumbawa mare's milk decreased from $1.41 \%$ to $1.26 \%$ on day 0 until day 15 . The decreasing of fat content during this period could occur due to the lipolytic activity of bacteria mainly lactic 
acid bacteria (Bao et al. 2015). The lipolytic activity of lactic acid bacteria can produce a distinct aroma caused by fatty acid oxidation into ketone (Hassan et al. 2012). Therefore, after day 15, the fat content on Sumbawa mare's milk steady increased until day 60 (Table 2). The accumulation of free fatty acid due to the lipolytic activity of lactic acid bacteria was able to increase the total fat content of the mare's milk (Coşkun \& Öndül 2004).

Ash content of mare's milk ranged from $0.32 \%$ to $0.61 \%$ based on the mare lactation period (Schryver et al., 1986). The increasing ash content during the fermentation process can be caused by other milk component reductions such as carbohydrate and fat (Obadina et al. 2013). Meanwhile, the water content of Sumbawa mare's milk increased which was in contrast to the decrease of carbohydrate and total sugar content. The increasing water content occurred due to sugar was metabolized using tricarboxylic acid cycle by lactic acid bacteria and produced $\mathrm{CO}_{2}$ and $\mathrm{H}_{2} \mathrm{O}$ (Mamlouk and Gullo 2013).

The bacterial density in the initial of fermentation (day 0) was ranged from 2.62 to $3.14 \log 10 \mathrm{CFU} / \mathrm{mL}$. The value was different in every medium. Raw mare's milk had lower bacterial density than raw cow milk, the average just $4.6 \log$ CFU/mL (Doreau \& Martin-Rosset 2011; Salimei \& Fantuz 2012). This value can be different due to horse type, and lysozyme and lactoferrin activity of the milk (Šarić et al. 2012).

The rarefaction curve of all fermentation periods already reached its plateau, which means that the sequencing depth already covered the bacterial diversity (Zhao et al. 2020). Lactobacillus helveticus was the most dominant species throughout the fermentation process of Sumbawa mare's milk. Lactobacillus helveticus was also found as dominant species in airag, which this species had high proteolysis ability (Miyamoto et al. 2015). Lactobacillus helveticus was first isolated by Orla-Jensen from Emmental cheese (Naser et al. 2006). Other lactic acid bacteria groups were also detected in a lower relative abundance representing Lactococcus, Lactobacillus pontis, Lactobacillus zeae, and Lactobacillus delbrueckii. The role of lactic acid bacteria in producing a natural antimicrobial agent which can enhance the shelf-life of the milk and serve as a beneficial microorganism (Benkerroum et al. 2000).

Citrobacter is a common intestinal microbiota of humans and animals, usually are harmless commensals, but several species such as Citrobacter freundli capable of acting as an opportunistic pathogen
(Fusco et al. 2018). Meanwhile, Methylobacterium komagatae are facultative methylotrophic bacteria that can be found almost in every habitat such as soil, freshwater, lake sediment and have a close association with plants (Bracke et al. 2000; Nercessian et al. 2005; Crump \& Koch 2008; Kato et al. 2008; Podolich et al. 2009). However, the relative abundance of potential pathogenic bacteria was detected in a low number. This can happen due to the competitive advantage of lactic acid bacteria by producing some antimicrobial substances especially organic acids, and bacteriocins (Singh 2018). The relative proportion of identified bacteria was higher than the unclassified and uncharacterized bacteria suggested that the identified bacteria play an pivotal role in the natural fermentation process.

The utilization of both culture-dependent and culture-independent analyses to observe the dynamic of the bacterial population of Sumbawa mare's milk during natural fermentation successfully showed the dynamic of bacteria throughout the fermentation process. However, this technique still needs to be improved, due to no correlation between the result of culture-dependent and culture-independent methods. By using metagenomic approach, Lactobacillus helveticus was detected in all fermentation s, however, in the culture-dependent method, the bacterial density on MRS agar and M17 agar gradually decreased until no bacterial colonies found on day 60 . This can be occurred due to specific growth requirements for certain bacteria (Zhao et al. 2020). Another example was several sequences cannot be annotated into species level due to discrepancy of sequence with Greengenes database. If the database cannot match the sequence until the species level, it will correspond to the upper taxonomic level (Shangpliang et al. 2018). Further study required to be conducted to confirm this dominant bacterium using dependent-culture method.

\section{ACKNOWLEDGEMENTS}

This study was funded by Hibah Peneliti Pemula (DIPA-023.17.2.677512/2020), Universitas Brawijaya.

\section{REFERENCES}

Data Centre and Information System for Agriculture. 2016. Buku outlook komoditas peternakan: Susu sapi [Book of outlook for commodity animal husbandry: Cow's milk]. The General Secretariat of the Ministry of Agriculture. 61 p. Available from: 
http://epublikasi.pertanian.go.id/download/file/547outlook-susu-sapi-2019.

Barboza PS, Parker KL, Hume ID. 2009. Carbohydrates: Sugars, fiber and fermentation. In: Barboza PS, Parker KL, Hume ID, editors. Integrative wildlife nutrition. Heidelberg: Springer. p. 97-118. doi: 10.1007/978-3540-87885-8 6.

Bao Z, Xiong J, Lin W, Ye J. 2015. Profiles of free fatty acids, free amino acids, and volatile compounds of milk bases fermented by Lactobacillus casei GBHM-21 with different fat level. CyTA - J Food. 14(1):10-17.doi: 10.1080/19476337.2015.1035673.

Benkerroum N, Oubel H, Zahar M, Dlia S, Filali-Maltouf A. 2000. Isolation of a bacteriocin-producing Lactococcus lactis subsp. lactis and application to control Listeria monocytogenes in Moroccan jben. J. Appl. Microbiol. $89(6): 960-968$. doi: $10.1046 / \mathrm{j} .1365$ 2672.2000.01199.x.

Bracke N, Van Poucke M, Baert B, Wynendaele E, De Bels L, Van Den Broeck W, Peelman L, Burvenich C, De Spiegeleer B. 2014. Identification of a microscopically selected microorganism in milk samples. J Dairy Sci. 97(2):609-615. doi: 10.3168/jds.2013-6932.

Bolyen E, Rideout JR, Dillon MR, Bokulich NA, Abnet CC, Al-Ghalith GA, Alexander H, Alm EJ, Arumugam M, Asnicar F, Bai Y. 2019. Reproducible, interactive, scalable and extensible microbiome data science using QIIME 2. Nat. Biotechnol. 37(8):852-857. doi: 10.1038/s41587-019-0209-9.

Callahan BJ, McMurdie PJ, Rosen MJ, Han AW, Johnson AJ, Holmes SP. 2016. DADA2: High-resolution sample inference from Illumina amplicon data. Nat. Methods. 13(7):581-583. doi: 10.1038/nmeth.3869.

Coşkus H, Öndül E. 2004. Free fatty acid accumulation by mesophilic lactic acid bacteria in cold-stored milk. J. Microbiol. 42(2):133-138. Available from: https://www.koreascience.or.kr/article/JAKO2004119 22358215.pdf.

Crump BC, Koch EW. 2008. Attached bacterial populations shared by four species of aquatic angiosperms. App. Environ. Microbiol. 74(19):5948-5957. doi: 10.1128/AEM.00952-08.

De Man JC, Rogosa M, Sharpe ME. 1960. A Medium for the cultivation of lactobacilli. J. Appl. Microbiol. $23(1): 130-135$. doi: $10.1111 / \mathrm{j} .1365$ 2672.1960.tb00188.x.

Doreau M, Martin-Rosset W. 2002. Animals that produce dairy foods: Horse. In: Fuquay JW, Fox PF, McSweeney PLH, editors. Encyclopedia of dairy sciences. London: Academic Press.

Fusco V, Abriouel H, Benomar N, Kabisch J, Chieffi D, Cho GS, Franz CM. 2018. Opportunistic food-borne pathogens. In: Grumezescu AM, Holban AM, editors. Food safety and preservation. Cambridge: Academic
Press. pp. 269-306. doi: 10.1016/B978-0-12-8149560.00010-X.

Gemechu T. 2015. Review on lactic acid bacteria function in milk fermentation and preservation. Afr. J. Food Sci. 9(4):170-175. doi: 10.5897/AJFS2015.1276.

Goulding DA, Fox PF, O'Mahony JA. 2020. Milk proteins: An overview. In: Boland M, Singh H, editors. Milk proteins (Third Edition). Cambridge: Academic Press. pp. 21-98. doi: 10.1016/B978-0-12-815251-5.000025.

Hassan FAM, Mona AM, El-Gawad A, Enab AK. 2013. Flavour compounds in cheese (review). Int J Acad Res. 4(5):169-181. doi: 10.7813/2075-4124.2012/45/A.20.

Hoyles L, Swann J. 2019. Influence of the human gut microbiome on the metabolic phenotype. In: Lindon JC, Nicholson JK, Holmes E, editors. The handbook of metabolic phenotyping. Amsterdam: Elsevier. pp. 535-560. doi: 10.1016/B978-0-12-812293-8.00018-9.

Kato Y, Asahara M, Goto K, Kasai H, Yokota A. 2008. Methylobacterium persicinum sp. nov., Methylobacterium komagatae sp. nov., Methylobacterium brachiatum sp. nov., Methylobacterium tardum sp. nov. and Methylobacterium gregans sp. nov., isolated from freshwater. Int. J. Sys. Evol. Microbiol. 58(5):11341141. doi: 10.1099/ijs.0.65583-0.

Klindworth A, Pruesse E, Schweer T, Peplies J, Quast C, Horn M, Glöckner FO. 2013. Evaluation of general 16S ribosomal RNA gene PCR primers for classical and next-generation sequencing-based diversity studies. Nucleic Acids Res. 41(1):e1. doi: 10.1093/nar/gks808.

Malacarne M, Martuzzi F, Summer A, Mariani P. 2002. Protein and fat composition of mare's milk: Some nutritional remarks with reference to human and cow's milk. Int. Dairy J. 12(11):869-877. doi: 10.1016/S0958-6946(02)00120-6.

Mamlouk D, Gullo M. 2013. Acetic acid bacteria: Physiology and carbon sources oxidation. Indian J. Microbiol. 53(4):377-384. Doi: 10.1007/s12088-0130414-z.

McDonald D, Price MN, Goodrich J, Nawrocki EP, DeSantis TZ, Probst A, Andersen GL, Knight R, Hugenholtz P. 2012. An improved Greengenes taxonomy with explicit ranks for ecological and evolutionary analyses of bacteria and archaea. ISME J. 6(3):610-618. doi: 10.1038/ismej.2011.139.

Miyamoto M, Ueno HM, Watanabe M, Tatsuma Y, Seto Y, Miyamoto T, Nakajima H. Distinctive proteolytic activity of cell envelope proteinase of Lactobacillus helveticus isolated from airag, a traditional Mongolian fermented mare's milk. Int. J. Food Microbiol. 197:6571. doi: 10.1016/j.ijfoodmicro.2014.12.012.

Mulyawati AI, Jatmiko YD, Mustafa I, Ardyati T, Suharjono. 
2019. Diversity of lactic acid bacteria isolated from fermented mare's milk products based on PCR-RFLP analysis. IOP Conf. Ser.: Earth Environ. Sci. 230 012104.

Naser SMK, Hagen E, Vancanneyt M, Cleenwerck I, Swings J, Tompkins TA. 2006. Lactobacillus suntoryeus Cachat and Priest 2005 is a later synonym of Lactobacillus helveticus (Orla-Jensen 1919) Bergey et al. 1925 (Approved Lists 1980). Int. J. Sys. Evol. Microbiol. 56(2):355-360. doi: 10.1099/ijs.0.64001-0.

Nercessian O, Noyes E, Kalyuzhnaya MG, Lidstrom ME, Chistoserdova L. 2005. Bacterial populations active in metabolism of $\mathrm{C} 1$ compounds in the sediment of Lake Washington, a freshwater lake. App. Environ. Microbiol. 71(11):6885-6899. doi: 10.1128/AEM.71.11.6885-6899.2005.

Obadina AO, Akinola OJ, Shittu TA, Bakare HA. 2013. Effect of natural fermentation on the chemical and nutritional composition of fermented soymilk nono. Niger. Food J. 31(2):91-97. doi: 10.1016/S01897241(15)30081-3.

Prioult G, Pecquet S, Fliss I. 2005. Allergenicity of acidic peptides from bovine $\beta$-lactoglobulin is reduced by hydrolysis with Bifidobacterium lactis NCC362 enzymes. Int. Dairy J. 15(5):439-448. doi: 10.1016/j.idairyj.2004.09.001.

Podolich O, Laschevskyy V, Ovcharenko L, Kozyrovska N, Pirttilä AM. 2009. Methylobacterium sp. resides in unculturable state in potato tissues in vitro and becomes culturable after induction by Pseudomonas fluorescens IMGB163. J. App. Microbiol. 106(3):728-737. doi: 10.1111/j.1365-2672.2008.03951.x.

Salimei E, Fantuz F. 2012. Equid milk for human consumption. Int. Dairy J. 24(2):130-142. doi: 10.1016/j.idairyj.2011.11.008.

Šarić LĆ, Šarić BM, Mandić AI, Torbica AM, Tomić JM, Cvetković DD, Okanović ĐG. 2012. Antibacterial properties of Domestic Balkan donkeys' milk. Int. D a i r y J . 25 ( 2) : $142-146$. d o i : 10.1016/j.idairyj.2012.03.007.

Savijoki K, Ingmer H, Varmanen P. 2006. Proteolytic systems of lactic acid bacteria. App. Microbiol. Biotechnol. 71(4):394-406. doi: 10.1007/s00253-0060427-1.

Schryver HF, Oftedal OT, Williams J, Soderholm LV, Hintz HF. 1986. Lactation in the horse: The mineral composition of mare milk. J. Nutr. 116(11):2142-2147. doi: $10.1093 / \mathrm{jn} / 116.11 .2142$.

Shangpliang HN, Rai R, Keisam S, Jeyaram K, Tamang JP. 2018. Bacterial community in naturally fermented milk products of Arunachal Pradesh and Sikkim of India analysed by high-throughput amplicon sequencing. Sci. Rep. 8(1):1532. doi: 10.1038/s41598-018-19524-6.

Shi T, Nishiyama K, Nakamata K, Aryantini NPD, Mikumo D, Oda Y, Yamamoto Y, Mukai T, Sujaya IN, Urashima T, Fukuda K. 2012. Isolation of potential probiotic Lactobacillus rhamnosus strains from traditional fermented milk produced in Sumbawa island of Indonesia. Biosci. Biotechnol. Biochem. 76(10):18971903. doi: 10.1271/bbb.120385.

Singh VP, 2018. Recent approaches in food bio-preservation - A review. Open Vet. J. 8(1):104-111. doi: 10.4314/ovj.v8i1.16.

Spinnler HE, Berger C, Lapadatescu C, Bonnarme P. 2001. Production of sulphur compounds by several yeasts of technological interest for cheese ripening. Int. Dairy J. 11(4):245-252. doi: 10.1016/S0958-6946(01)00054-1.

Sujaya N, Ramona Y, Widarini NP, Suarini NP, Dwipayanti NMU, Nocianitri KA, Nursini NW. 2008. Characterization of lactic acid bacteria isolated from Sumbawa mare milk. J. Veteriner. 9(2):52-59. Available from: https://ocs.unud.ac.id/index.php/ jvet/article/view/3314.

Süle J, Kõrösi T, Hucker A, Varga L. 2014. Evaluation of culture media for selective enumeration of bifidobacteria and lactic acid bacteria. Braz J. Microbiol. 45(3):1023-1030. Doi: 10.1590/S151783822014000300035.

Tzvetkova I, Dalgalarrondo M, Danova S, Iliev I, Ivanova I, Chobert JM, Haertlé T. 2007. Hydrolysis of major dairy proteins by lactic acid bacteria from Bulgarian yogurts. J. Food Biochem. 31(5):680-702. doi: 10.1111/j.17454514.2007.00137.x.

Uniacke-Lowe T, Huppertz T, Fox PF. 2010. Equine milk proteins: Chemistry, structure and nutritional significance. Int. Dairy J. 20(9):69-629. doi: 10.1016/ j.idairyj.2010.02.007.

Widyastuti Y, Rohmatussolihat, Febrisiantosa A. 2014. The role of lactic acid bacteria in milk fermentation. Food Nutr. Sci. 5(4):435-442. doi: 10.4236/fns.2014.54051.

Yao G, Yu J, Hou Q, Hui W, Liu W, Kwok LY, Menghe B, Sun T, Zhang H, Zhang W. 2017. A perspective study of koumiss microbiome by metagenomics analysis based on single-cell amplification technique. Front. Microbiol. 8:165. doi: 10.3389/fmicb.2017.00165.

Zhao J, Fan H, Kwok LY, Guo F, Ji R, Ya M, Chen Y. 2020. Analyses of physicochemical properties, bacterial microbiota, and lactic acid bacteria of fresh camel milk collected in Inner Mongolia. J. Dairy Sci.103(1):106116. doi: 10.3168/jds.2019-17023. 